\title{
Skills and the social value of work
}

\author{
Patricia Findlay
}

\section{Introduction}

'The most important capital for the world of work ahead is skills' (EPSC, 2016).

Skills matter, and not just to the people who have them. Skills are crucial supports for work and employment and for individual economic prosperity, but are valuable far beyond this, impacting upon social mobility, health and well-being and social and civic life. Employers also have a direct interest in skills, their acquisition, formation, development and, perhaps most crucially, how skills are deployed, as is clear from numerous discussions of, and programmes in, talent management. Worker skills are valuable to capital, and employers have a strong vested interest not just in the effectiveness of how they access, develop and retain skills but also in how public policy and public investment supports national education and skills systems. Skills also serve a crucial social function, providing the basis not just for wealth creation but also underpinning success, broadly defined, for families, communities and civil society.

In recent years, there has been seen increasing academic and policy interest in skills (Toner, 2011). Governments have a longstanding interest in skills and in how their role in the skill system can support economic performance and innovation as a crucial element of sustained economic performance. Over recent decades and across a range of countries, skills acquisition has been viewed increasingly as the solution to a range of range of individual, organisational and societal ills - the lever that improves individual and household wealth and well-being, unlocks organisational assets leading to greater efficiency and innovation whilst also addressing important social priorities such as reducing poverty and income inequality, eliminating unfair discrimination, improving life chances and increasing social mobility. In Britain, the Leitch review (Leitch Review of Skills, 2006) illustrated the core role of skills in public policy discourses around work, a role ascribed to skills well beyond the UK. At a European level, the Lisbon agenda focus on 'more and better jobs' emphasised the role of improving workforce skills in improving productivity in an increasingly competitive global economy (Fernández-Macías \& Hurley, 2014). Building on this, 'An agenda for new skills and jobs' emerged as one of the flagship initiatives of the Europe 2020 strategy, further reinforcing the importance of lifelong skills acquisition and development (Cedefop, 2012) to reduce individual vulnerability to skill-biased technological change and to increase the resilience of national economies.

In Europe and beyond, skills policies are increasingly important levers through which governments influence the economy and intervene in peoples' lives (Keep, 2016). Arguably, skills policies, supported by public education and training systems, are now the most used lever of national governments 'silver bullets' deployed to solve a wide array of economic and social problems from low relative productivity or slow productivity growth to reducing inequality (Keep \& Mayhew, 2014). Toner (2011) argued that neo-liberal economic policies in most developed countries have emphasized the supply of skills to the labour market rather than more active industrial policies - reflecting Fernandez and Hayward's assessment that '... intervening on the supply-side through education and training has become almost the only socially and politically acceptable way for government policy to be used to raise the economic competiveness of organisations' (Fernandez \& Hayward, 2004).

Yet notwithstanding the importance of skills policy, part of the prevailing narrative around skills is not to argue for greater state intervention in this area but to shift responsibility for acquiring skills and enhancing human capital to the individual. Individuals are increasingly exhorted to invest in skills 
acquisition to make themselves more marketable and employable. Yet access to skills and returns from skills vary widely, and with the issue also being raised of whether or not too much is being asked of skills and skills policy.

This chapter analyses skill in work through a broader political economy lens that allows for greater understanding of the competing and complementary priorities and experiences of multiple actors individuals, employers and the state primarily - in relation to skills, and the potential for approaches to skills in work to drive - or to thwart - individual, economic and social progress (Green, 2012; Green, 2011). The starting point is a consideration of the challenges in defining, understanding and analyzing skills. In the next section, an examination is made of the value of skills, both in terms of returns to having skills and qualifications, and in terms of the organizational processes and practices for skills valuation. The following section considers key trends in workforce and workplace skill, while the penultimate section looks beyond the 'possession' of skills to consider how these are deployed in the workplace. The final section turns to approaches to skills in distinct country and institutional settings and the role of skills policy in leveraging change in how skills are defined, understood, valued and used. The chapter then concludes by presenting to possibility of a more progressive agenda for skills and the challenges in making this agenda a reality in the contemporary context.

\section{Understanding and analysing skill}

Skill is a complex concept and there is no single accepted definition either for analysis or for policy making. As Lafer (2002) notes: 'The notion of 'skill' has been one of the most elusive and hardest todefine concepts in labour economics'. Skill incorporates the ability to do something, to do it well and to be able to do it because of knowledge, effort, experience and practice - all of which point to the notion of proficiency in a task or activity that can be technical, cognitive and interpersonal or encompass elements of each. An expansive definition of skill includes a wide spectrum of components from knowledge to occupation-specific competences and individual attributes (Toner, 2011). The most common proxies for skill focus on accredited knowledge - primarily education and qualifications - and occupation. Many analyses of skill span both, combining attention to education, training and experience (Machin \& Van Reenan, 1998). Employee or employer perceptions of required skill levels also feature (Felstead, et al., 2002). Perhaps surprisingly, job tasks and attributes are less commonly used to identify and measure skill, although exceptions exist which will be returned to below (Howell \& Wolff, 1991; Esposto, 2008).

All of these indicators are problematic in different ways, particularly when it comes to data availability and measurement. Put simply, while data on years and levels of education and qualifications obtained are relatively straightforward to measure, these do not and cannot tell the whole story about skills either at an individual, occupational or labour market level, not least because education and qualifications tell us little about skills actually used on the job, or about skills acquired informally on or off the job (Payne, 2010). Keep (2016) has noted the work of Wright and Sissons (2012) in highlighting the challenges of using qualifications-based metrics in the hospitality sector.

In a similar vein, the use of occupational data as a proxy for skills and skill trends has also been criticised for three notable reasons. First, occupational skills are not static and skill change cannot readily be captured solely through measures of occupational change (Green, et al., 2016). Second, in certain labour market conditions 'credentialism' leads to a disjuncture between the skills required to do a job and the skills required to get that job (Findlay \& Warhurst, 2012). Third, evidence suggests that job tasks and the skills required to complete them vary substantially within as well as across occupations (Autor \& Handel, 2013). Yet, despite these limitations, occupational data continues to be widely used as a proxy for skills. 
In recent decades, the definition of skill has been expanded to include '... what are variously termed 'generic', 'transferable' or 'employability' skills (Toner, 2011, p. 14). These include team-working skills, motivation, attitudes to discipline and enthusiasm among others (Lloyd \& Payne, 2009) as well as emotional skills and articulation (Hampson \& Junor, 2005). Moss and Tilly define this broad group of attributes as 'soft skills' - 'skills, abilities and traits that pertain to personality, attitude and behaviour rather than to formal or technical knowledge' (Moss \& Tilly, 1996, p. 253).

Keep and Payne (2004), following Keep and Mayhew (1999), see this as a re-labelling of behaviours, personal attributes, attitudes and dispositions as skill to the point where 'the concept of skill becomes essentially meaningless', stripped of any rigorous and measurable way of defining competence in the 'skill' (Keep \& Payne, 2004, p. 57). Despite these reservations, Grugulis (2004) argues that rebranding personal attributes and qualities as skills is now well entrenched in the discourse of employers and policymakers.

These contested debates over the broadening of the concept of skill highlight simultaneously the challenges in defining skill and the importance of defining it and measuring skill robustly. Cockburn (1983) has argued that definitions of skills span skill in the person, skill in the job, and skill in the social setting, and that all three are important to an understanding of the concept. Green (2011) defines skill as a personal quality that is productive (creates value); that is expandable (improved by training and development) and that is social (in that skills are socially determined). Both of these typologies are useful in understanding skill in terms of human capital, job tasks and the social construction of skill.

\section{Skill in the person}

Skill in the person focusses on skill as an individual quality, attribute, capacity or behaviour that is acquired through education, training and experience. Along with their health, skill is widely seen as a core component of an individual's human capital (Green, 2011). Education and training are investments in skill that should enhance human capital. Toner's review of skill for the OECD (2011) highlights two key assumptions that underpin discussions of human capital. The first assumption is that human capital analogous to physical capital, so investing in human capital through education and training increases labour productivity - and should, in theory, raise the value of labour. The second assumption is that investment in the quality of labour increases the complementarity between labour and capital as higher quality labour raises the productivity of capital, stimulating further capital investment that in turn increases the demand for skilled labour. Across countries, additional human capital - more years of schooling or better qualifications - is closely correlated with hourly earnings, and at a country level, educational attainment is strongly related to per capita GDP. The relationship between human capital and earnings at an individual level arises through a variety of mechanisms including the acquisition of new knowledge and skills, the signalling of innate ability and the operation of credentials in labour market allocation (Toner, 2011; Wolf, 2004).

Yet not everyone has equal access to the educational opportunities required to build human capital and develop skill. While important progress has been made in closing and in some cases reversing a gender gap in educational attainment, other gaps are stubbornly persistent, notably in relation to socio-economic status. In Britain, a significant attainment gap is evident between young people from privileged and disadvantaged backgrounds comprising a performance gap (in terms of examinations results and qualifications obtained) and an outcomes gap (in terms of what qualifications deliver in accessing the best universities and jobs) (Keep \& Mayhew, 2014; Tomlinson, 2008). This gap thus reflects not just the operation of the education system but also of the labour market.

In recent decades, 'soft skills' have become increasingly prominent in employers' hiring approaches. Soft skills include "... personality traits, goals, motivations, and preferences that are valued in the labor 
market' (Heckman \& Kautz, 2012). While acknowledging the importance of these 'soft skills', some have sounded a note of caution in separating 'soft' from technical or achieved skills. As Lloyd and Payne argued: '... unless skill has a clear link to technical knowledge and competence (in its broad sense), there is real danger that as a concept it will become ever more meaningless and ultimately redundant' (Lloyd \& Payne, 2009, p. 631). Warhurst, Tilly and Gatta dispute this, arguing that it represents a nostalgic and productionist view of skills as '... 'hard' technical and certified abilities and knowhow delivered through apprenticeships in unionized workplaces' $(2017$, p. 74$)$ which fails to take sufficient account of the scale of change in work and skill since the 1950s. The issue of how different skills are both social constructed and differentially valued shall be returned to later in the chapter.

\section{Skills development}

Education and qualifications derived from education represent an important investment in human capital by individuals and, in many advanced societies in particular, by the state through publicly provided education systems. School, tertiary and higher education largely 'frontload' human capital acquisition and development. Yet, as $\operatorname{EPSC}(2016$, p. 1) noted, 'skills are not static and need to be updated and fine-tuned throughout working lives'. Adult and lifelong learning and skills formation are increasingly important and, given that these processes are not served well by public skills and learning systems, there is little doubt that 'the primary location for the creation and development of higher order work skills remains the workplace' (Keep \& Payne, 2004, p. 68).

Unfortunately, however, research tells us that in-work skills acquisition is also significantly stratified. Workplace skills acquisition is not equally accessible to all, with workers in the poorest quality jobs and with the lowest formal qualifications least likely to access training and skills development. Those most likely to access employer-funded training - and to access more of it - are those with higher initial educational attainment and in particular higher level occupations. To illustrate, for Australia, Draca and Green (2004, p. 622) argued that workers with higher qualifications are significantly more likely to receive training from their employer than workers with vocational or trade qualifications, while managers, professionals and associate professionals receive almost three times more hours of training that those in clerical occupations and five times more hours of training than tradespeople. This echoes earlier findings for Britain (Arulampalam \& Booth, 1998) that education and training are highly complementary.

This complementarity - where those with more education are also likely to receive the most training - has some plausible explanations (Toner, 2011), for example, in relation to variation in occupational demands. However, it also reflects wider labour market disadvantage. Access to workplace or workbased training and skills development varies also by contractual status, sector of employment and firm size. As Lindsay, Canduela and Raeside (2012) found that processes of labour market polarisation in Britain have impacted upon training provision with evidence that older workers, those with lower skills and qualifications, part-time and temporary workers are less likely to be able to access training. Firms with business models that rely on flexible employment have a lower propensity to train (Draca \& Green, 2004). The growth of atypical forms of employment (self-employment, temporary and agency working) reflects variation in business models and approaches to accumulation, and simultaneously generates labour market failure in relation to training and skills development as firms avoid the costs (and the benefits) of skills investment, workers face reduced opportunities and incentives to engage in workplace training and society fails to capitalise fully on public investments in education and training. As EPSC noted, almost half of permanent employees received training compared to $32 \%$ of employees on fixed contracts and only $19 \%$ of those who are self-employed, such that ' ... it is often the case that those who need life-long training the most are those who have the least access to it' (EPSC, 2016, p. 7). 
Turning to firm size and sector, Edwards (2010) noted that the half of the British workforce employed in small firms suffer a double disadvantage: they access less training and skills development than workers in larger firms, and that training and development tends to be less formalised and hence less easily transferable to other employment. A positive association has been found between the likelihood of receiving training and public sector employment. The presence of unions can, however, reduce some of the inequalities in access to training in the private sector (Lindsay, et al., 2012; Sousounis \& Bladen-Hovell, 2010). Across Europe, there are concerns that front-loaded educational systems are poorly designed to deliver the type of lifelong learning required to support the more frequent employment and work transitions that are likely in future, and that learning and skills acquisition are required across the life course - that is, at all stages when workers are economically active. This creates particular challenges in liberal market economies where greater emphasis is placed on individual responsibility for skills acquisition, human capital formation and development rather than on the roles and responsibilities of employers in ensuring continuing development and lifelong learning.

\section{Skill in the job}

The focus above was on skill as embodied in an individual. Another important way of thinking about skill is to focus on where and how skill is deployed - that is, through tasks that are configured into jobs within a production or service delivery process (Green, 2011). This sociologically informed approach ties the concept of skill more closely to its productive application in creating value and distinguishes tasks by the types of knowledge they require, their level of complexity and by the degree of autonomy available to workers in exercising their skills, with more complex tasks associated with greater worker autonomy (Green, 2011).

Most datasets on skill rarely say anything about job tasks. As Autor and Handel noted: 'The primary research data sets used for studying employment and earnings provide rough measures of workers' human capital, such as education, potential experience ... but essentially no information on their job tasks' (Autor \& Handel, 2013, p. s61). The most notable exception to this is the US Department of Labour's Occupational Information Network (successor to their Dictionary of Occupational Titles which operated from 1938 until the late 1990s) which defines occupations by job characteristics, grouped by factors such as education and training requirements, tasks, technology skills, knowledge, skills, abilities, physical demands, work activities and physical work context. Originally designed to support job seekers, employers and employment support service workers, the information offered (drawn from on-site observation of jobs) has use in research on skills and jobs (Cain \& Treiman, 1981), although it is not without limitations. Autor and Handel (2013) drew upon this data and have highlighted that variation in observed job tasks and content exists within and between occupations and that such within-occupation variation is systematically related to workers' race, gender and English language proficiency. This finding, amongst others, suggests that skill in the job is not neutral and is closely connected to the characteristics of those who exercise the skill. This issue is returned to below.

While quantitative datasets on skill in the job are thin on the ground, extensive qualitative research exists on skills and job content within specific occupations, and on how these are changing, in part consequent on developments in regimes of accumulation and modes of regulation and in part consequent on technological change. Some of the most significant insights into skill in the job have derived from in-depth qualitative or ethnographic accounts of particular occupations. Barley's (1996) much cited ethnography of technical workers was a response to the limited number of accounts of how work was changing despite a proliferation of accounts of widespread economic, organisational and technological change. Barley's analysis illustrates both the challenges of, and the insights from, 
efforts to fully understand the complexities of skills development, deployment and utilisation and how these related to wider occupational, organisational, managerial and external structures.

In understanding contemporary developments in the allocation of skills and tasks across occupations, there is strong interest in the interaction of skills and emerging technologies. As Vallas (1990) noted, there are two dominant perspectives (notwithstanding important variations within each theoretical camp): one that associates emerging technologies with upskilling (Blauner, 1964) and one that sees technology as producing deskilling (Braverman, 1974). While it has long been recognised that skillbiased technical change augurs badly for unskilled labour as the relative demand for skilled labour increases, a broad pervasive tendency towards deskilling in contemporary capitalism has been extensively critiqued (for a review, see (Attewell, 1987). While data on compositional shifts in skill may not support a deskilling thesis, however, this does not preclude deskilling of particular occupations, as many case studies of occupational work illustrate (Vallas, 1990).

More recently, apocalyptic predictions about the reach of technology-driven skills obsolescence have emerged, with recent concerns over the role of machine-based learning in substituting for some of the higher level skills of professional workers (Marr, 2016). Notwithstanding the scale and longevity of predications as to the potential for technology to drive elimination or deskilling of labour, much evidence suggests that technological innovation and investment in human capital are mutually reinforcing (Lloyd-Ellis \& Roberts, 2002). As Toner noted, '... at an economy-wide level an increase in the capital-labour ratio and other innovation-related investments such as R\&D and organisational restructuring are associated with an increase in the supply of and demand for higher skills' (Toner, 2011, p. 7). Yet this does not tell the whole story and there is evidence that technological change and innovation can impact negatively on the skill content of particular jobs.

It is, of course, important to recognise that technology does not determine skills outcomes and that employers/managers can choose how to align employees' skills with technology in ways that retain and develop skills and enhance job quality (Findlay, et al., 2017a) Findlay et al.'s (2017b) study examined the introduction of automated drugs dispensing in a hospital setting. While robotics technologies delivered picking and packing roles previously carried out by pharmacy workers, efforts were made to up skill employees by redirecting their work effort towards high value added, patientfacing work, resulting in improved job quality for most workers.

\section{Skill in the social setting - the social construction of skills}

Why are certain capabilities described as skills, and why are some skills considered more valuable in employment than others? These questions may appear prosaic, but are crucial to any understanding of the way society constructs skill. As Green argued, 'regarding human capital as a thing to be acquired, like other capital, the neoclassical concept misses the social context of skill ... The acquisition of skill is conditioned by attitudes and expectations that are imprinted with social norms; while opportunities for skill acquisition are circumscribed by social class. The value of skill is perturbed by the 'social construction of skill', whereby social processes, including power, affect who can sport the label of 'skilled labour', and who can claim the rewards' (Green, 2011, p. 9). Social power upsets (or 'perturbs') any easily read-off relationship between more objective aspects of skill and whether these are designated or accepted as skills. Some authors have usefully offered the distinction between this 'ascribed' skill and 'achieved' skill (proxied by qualification) (Warhurst, et al., 2017).

Acknowledging the social construction of skill means acknowledging skill is a contested political concept subject to social and ideological processes that are distinct from the technical composition of tasks and jobs (Littler, 1982; Vallas, 1990). Much of the critical sociological literature on the social construction of skill derives from studies of the interaction of gender, skills and work/employment. 
From Cockburn's (1983) study of women in the print industry, through debates on emotional labour to recent debates on service, and particularly personal service, work, Phillips and Taylor's conclusion that 'skill definitions are saturated with sexual bias' (Phillips \& Taylor, 1980, p. 79) seems especially prescient.

It is not only the experience of women workers that remind us that the term 'skilled' is contested and that skills 'should not be regarded as an immutable, independent, quality of individuals' (Green, 2011, p. 11). Skill definitions and what is recognised as skill are also saturated with racial and class bias and the rising importance of 'soft skills' may well have accentuated this bias. As Warhurst et al. argue: 'Soft skills are par excellence an example of habitus that is moulded by upbringing, peer culture and early work experience' (2017, p. 86).

While the research base is considerably smaller, a similar picture to that of education emerges in that there is evidence in considerable stratification in who is seen to possess 'soft skills'. For the US, Moss and Tilly (1996) noted that black men are viewed as lacking in 'soft skills' in terms of motivation and interpersonal relations and interactions with colleagues and customers, which may in part explain their growing labour market disadvantage. Warhurst et al also note that to the extent that a segregated society generates subcultures correlated with racial identity, blacks will typically be less fluent in the dominant, 'white' culture that sets norms and expectations in most employment settings' (2017, p. 86).

Similarly in relation to class, Laurison and Friedman (2016) observed that people of different class backgrounds bring different resources - separately from skills and qualifications - into occupations. Class matters, and class origins do not always appear to be eliminated by the acquisition of qualifications and skills. As these authors noted, this impact of class origins matters well into the life course, and even those who experience occupational upward mobility 'face challenges stemming from their different social, economic, and cultural resources, class bias or a sense of emotional dislocation' (Laurison \& Friedman, 2016, p. 669). Similarly, in their study of estate agents in Britain, Tholen and colleagues (Tholen, et al., 2016) pointed to class-based 'soft skills' as a key element in accessing jobs and progressing in high value estate agency work. Class background has clear consequences for the returns available to individuals to the skills investments they make, a point returned to in the next section on the returns to skills and skills valuation. In the context of shifts towards more service jobs, a greater emphasis on soft skills, and a declining role of unions and a consequent rise in employers' power to define what is skilled, Warhurst et al. (2017) argue that a new social construction of skill has emerged that reflects a much more extensive ascription of skill, greater blurring of the lines between achieved and ascribed skill, and the replacement of forms of exclusion that explicitly discriminate against certain groups by a new discourse of merit that can be corralled to render social exclusion less visible but no less excluding.

\section{What is skill worth?}

Challenges in defining and measuring skill exacerbate challenges in valuing skills. Traditionally (neoclassical) economists value skills in exactly the way they value any other good, namely, the highest amount that any consumer or firm is willing to pay for it. Returns to various skills are measured by regressing the various characteristics of workers, including skills, on wages and looking at the marginal contribution (co-efficient) on various skill levels relative to some base level. Yet looking at data on women's pay, for example, alerts us to the glaring inconsistencies in the returns to skills and qualifications by gender and so to the limitations of mainstream economics explanations of what skills are worth, pointing us to the role of social construction in skills valuation. Thinking about the economic 'worth' of skills to individuals is increasingly important as the burden of responsibility for skills acquisition falls to individuals rather than to the state and/or employers. 
There are two large bodies of research in this area: the first focuses on the economic returns to individuals from having qualifications (as a proxy for skill); the second focuses on organisational valuation systems that determine pay. Both are important in addressing the question of whether or not skills acquisition pays.

\section{Earnings returns to qualifications}

There is an extensive academic and policy literature on individual returns to qualifications which provides an important evidence base from which to identify whether and how individuals, employers and the state should invest in skills and qualifications. Using aggregated data, there is much support for the view that investment in human capital pays off for individuals. Hanushek et al. (2013) estimated the lifetime returns to direct measures of cognitive skills across 22 countries, highlighting that there is, on average, an $18 \%$ wage increase corresponding to a one-standard- deviation increase in numeracy skills among prime-age workers. This figure masks substantial country variation, with higher corresponding figures for the US (28\%), Ireland and Germany (24\%) and Britain (22.5\%), and lower figures for all of the Nordic countries of less than $15 \%$.

Turning to qualifications, in Britain, having an undergraduate degree delivers a marginal earnings return of around $27.4 \%$ compared with having 2 or more GCE ' $A$ ' Levels (BIS, 2011). This return varies according to the type of degree studied. Vocational degrees such as medicine and dentistry generate the highest marginal returns $(82.8 \%)$, while above average returns are achieved by those with degrees in law, mathematics and computer science, engineering, architecture, business and administrative studies, social studies, and subjects allied to medicine. Undergraduate degrees in linguistics and European languages offer relatively lower earnings returns. In addition, higher classified degrees offer a higher earnings return (BIS, 2011).

However, earnings returns to degree qualifications vary by gender. For undergraduate degrees as a whole, and for some types of degree (medicine and dentistry degrees, for example), women post a higher marginal earnings return than do men, although the earnings premium for grade of honours degree is considerably steeper for men than for women - that is, men's relative earnings (to other men) are more influenced by honours grade than for women (BIS, 2011).

Similarly, there are strong positive wage returns to A levels (UK upper secondary qualifications equivalent to European Qualifications Framework Level 4) when compared with GCSEs/O levels (equivalent to EQF Levels 2 and 3 depending on grade), - irrespective of whether the individual goes on to complete further or higher qualifications (London Economics, 2015). These returns are greater for levels in science, technology, engineering and mathematics (STEM) compared to A Levels in other subjects. As with degrees, the earnings return for women are consistently greater than for men and the impact of the grade of A Level matters much more to men than to women (BIS, 2011).

The returns to vocational qualifications are, however, more complex, comprising variation across types, levels and subjects of vocational qualifications such that 'It is therefore not the case that a simple message about the returns to vocational qualifications can be delivered' (McIntosh \& Morris, 2016). Higher level vocational qualifications such as BTEC level 4/HND/HNC qualifications deliver, on average, higher estimated returns (averaging around 13\% when comparing the wages of those with and without such a qualification). Level 3 qualifications deliver smaller earnings returns than Level 4 qualifications, with the best returns of $7 \%$ arising from ONC/OND qualifications. Apprenticeships generate an average return of around 9\%. However, few Level 2 and Level 1 qualifications generate positive and statistically significant returns (McIntosh \& Morris, 2016). 
Vocational qualifications tend to deliver differential earnings returns to men and women. Unlike for degrees, women do less well in terms of earnings returns from HNC/HND qualifications (with $15 \%$ higher wages for men but $9 \%$ higher wages for women) and women do not earn a positive wage premium from apprenticeships and higher level City and Guilds qualifications, while men do not earn a positive wage premium from RSA qualifications (McIntosh \& Morris, 2016).

The arguments above make it clear that the economic value of investing in skills varies systematically by gender. There is also some limited evidence that it also varies by class although analysing this phenomenon is made more complex by the tendency to see occupation and hence skill as a proxy for class (Warhurst, et al., 2017). Laurison and Friedman's (2016) recent analysis of Britain's Labour Force Survey looks at the openness of high status occupations to people of different class backgrounds and at the earnings of the upwardly mobile within these occupations. Mobility from a working class background to a professional occupation does not deliver the same financial returns, with average earnings $17 \%$ less than those from privileged backgrounds, that is, up to $f 7,350$ lower annual earnings. These authors identify a 'class ceiling at play, which prevents upwardly mobile members of high-status occupations from enjoying equivalent earnings to people who come from inter-generationally stable backgrounds' (Laurison \& Friedman, 2016, p. 669). This class pay gap exists after controlling for other human capital and career factors that might explain it, indicating that 'the dominant, individualizing argument that inequality in earnings can largely be explained in terms of individual knowledge, credentials, and skill, appears fundamentally limited in a British context' (Laurison \& Friedman, 2016, p. 683).

\section{Organisational valuation of skills}

While labour market demand and supply shape the relative value of occupations, valuation of skills remains primarily determined at organisational level. As Green noted '... job analysis, built upon competence (skills, knowledge and attitudes) frameworks, delivers the normative valuation process that occupational psychology substitutes for market valuation ... Heterogeneous jobs are made comparable through commensurate grades using expert judgements about the competence levels involved, while educational qualifications are similarly ranked with descriptions of the competences they certify' (Green, 2011, p. 12).

These processes, while formally neutral, are, of course, heavily socially imbued, as is made clear in the research base on gender, skills and pay. As Findlay, Findlay and Stewart noted: 'Although 'soft' skills and emotional labour are increasingly recognized, their impact on skill valuation remains problematic. Many skills associated with women's work continue to be undervalued (Gottfried, 2006; Grimshaw \& Rubery, 2007; OECD, 1998), failing to reward visible emotional skills and/or insufficiently acknowledging technical skills (Hochschild, 1983; Steinberg \& Figart, 1999) ... many caring skills are not recognized as skills but as the natural, innate or acquired attributes of women (Moss, et al., 2006). This lack of recognition denies their learned (or earned) nature and defines them as unworthy of significant reward' (Findlay, et al., 2009, p. 423). In their study of early years workers, these authors noted that technical skills in children's education were 'contaminated' by their caring skills, leading to lower valuation of their skills. They point out that these jobs '... have been parsimoniously construed and their skills narrowly constructed largely because of gendered assumptions regarding their work. The caring dimension of their jobs appears to overshadow their significant role in education, and caring becomes the lens through which their work is viewed and measured' (Findlay, et al., 2009, p. 438), noting that these findings have implications for others whose work has a caring dimension.

Acknowledging the deeply embedded nature of organisational processes that lead to skills invisibility and devaluation requires better job evaluation and reward system design (Steinberg, 1990; Steinberg, 1999), as well as more explicit recognition of how these processes operate within union agendas. 
Undervaluation of women's skills produces a vicious circle whereby women's jobs are more likely to be perceived as low skilled, which justifies low pay and which, in turn, reinforces these jobs as not suitable for men, which perpetuates the types of occupational segregation that facilitate defining women's jobs as low skilled (Green, 2011). Understanding the contested nature of skill and the role of bias in designating skill can only be uncovered, as Green argued, through thorough analyses of job content. Focussing on the economic value of - or, more accurately, returns to - qualifications and skills says nothing, however, about their social value in improving quality of life, health and well-being, and life prospects for individuals, families and communities.

\section{What is happening to skills over time?}

There's never been a better time to be a worker with special skills or the right education, because these people can use technology to create and capture value. However, there's never been a worse time to be a worker with only 'ordinary' skills and abilities to offer, because computers, robots, and other digital technologies are acquiring these skills and abilities at an extraordinary rate (Brynjolfsson \& McAfee, 2014, p. 5).

The quote above highlights the changing role and value of skill across occupations. This trajectory of skill across occupations is crucial to understanding trends in occupational structure, the growth or contraction of occupations and related developments in skill formation. Trends in skills may differ depending on the definition of skill used. Put simply, different trends may be identified depending on whether or not the study is of qualifications (as a proxy for skill) or changes in the skills actually used or needed in jobs. If skill is measured by the qualifications held by people in the labour force, much of the evidence in advanced economies is of increasingly skilled people and jobs. Looking at the period from 1986-2012, Green et al. (2016) noted growth in the proportion of jobs requiring graduate level or equivalent qualifications from $20 \%$ to $37 \%$ and reduction in the number of jobs requiring no qualifications from $37 \%$ to $23 \%$. This pattern is replicated elsewhere - see Acemoglu and Autor (2011) for a discussion of the US, Fernandez-Macias and Hurley (2014) for a discussion of European countries and Toner (2011) for a review of OECD countries).

Broadening out from qualifications, Green et al. (2016) pointed to complementary indicators of skill, principally the amount of prior learning time required to do a job, and the cumulative amount of training in a job. In the decade up to 1997, both of these indicators increased, pointing to aggregate increases in skill in Britain. These indicators plateaued and then fell marginally in the period from 2000, which the authors argued might reflect that on-the-job learning was being substituted for by better education. While there is evidence of variation - physical skills were not becoming higher over the period 1986 to 2012, and the rising use of high literacy skills stalled after 2006 - Green and colleagues identify no evidence of a reversal of upskilling in Britain.

This picture is reflected in data from other countries. For OECD countries, Toner (2011) argued that economic expansion from 1995 till the global financial crisis produced similar patterns of aggregate skills upgrading and increases in the cognitive content of jobs, particularly in relation to more intensive information-processing tasks. While some research has pointed to a shift from upskilling in the US (Beaudry, et al., 2013), this is not consistent with the work of Acemoglu and Autor (Acemoglu \& Autor, 2011) who have highlighted similar upskilling trends or with Handel's (2016) findings of a gradual, long term process of skill upgrading in the US. Toner stated that 'The overall conclusion of most studies over the last three to four decades, albeit with some important exceptions, is that '[r]egardless of the measurement of skills ... demand for high-skilled labour has risen since the 1970s. This trend is observed in both the manufacturing ... and the service sector ... as well as in the aggregate economy. The higher the skill level of jobs or occupations, the greater the skill upgrading is likely to be' (Kim, 2002, p. 91)' (Toner, 2011, p. 12). 
As the quote at the start of this section clearly captures, however, aggregate trends conceal important variation, and upskilling has been accompanied by increasing polarisation in skills and labour market experiences, with skill levels rising in higher level occupations and skills development static or declining in intermediate and lower manual occupations (Gallie, 1999). Since the early 2000s, a growing and prominent literature has pointed to, variously; the decline or hollowing out o of intermediate occupations and the development of an 'hourglass' economy in the UK and elsewhere generating increasing 'polarization of a large group of skilled/qualified workers with access to continuous development, and growing numbers of unskilled people 'at the bottom' facing deskilling or stagnation' (Lindsay, et al., 2012, p. 207). Polarisation simultaneously threatens job quality 'at the bottom' and creates a gap between lower and higher level occupations that becomes too large to bridge.

A number of possible (and related) explanations for this polarisation have been offered. Many analyses point to the role of technological advances and the differential impact of computerisation on higher, intermediate and lower level occupations (Autor, 2010; Autor \& Handel, 2013). Higher occupations contain relatively fewer routine tasks that are capable of being substituted by technology. Lower level occupations are either not routine enough (for example, in the provision of personal services that require extensive social interaction) or are not cost efficient to automate when a supply of low cost labour is available. Intermediate occupations - primarily manufacturing, clerical and administrative jobs - comprising routine and programmable tasks are more at risk of technological substitution.

A second and related driver of polarisation is the internationalisation of labour markets, particularly for labour that can be connected through information technology (Autor, 2010; Acemoglu \& Autor, 2011) and the possibilities to offshore tasks internationally to take advantage of cheaper skills supply (Toner, 2011; Fernández-Macías \& Hurley, 2014). Beyond these explanations, Lindsay et al. (2012) identified a number of interrelated drivers of polarisation including persistent wage inequality in liberal market economies (LMEs) that has resulted in increasing demand for low-level service work to service the needs of higher earners and which reflect the skills needs of particular (low skills equilibrium) business models (Storey \& Salaman, 2008). In the UK, $15 \%$ of those in employment are considered to be 'over-educated' (ONS, 2016), contributing to the UK's fifth ranking in Europe for skills mismatch (ILO, 2014). Additionally for the UK, for the lowest skill level, there are half a million more jobs requiring no qualifications than individuals with no qualifications (Felstead, et al., 2007). Continuing demand for low skilled workers risks keeping these workers low skilled, not least as they are less likely to access or afford skills investment.

Staying with the focus on business models, while developments in the types of contracts and work available may not drive polarisation, developments in forms of work might exacerbate the challenges of polarisation. Shorter tenure, on demand work and rising self-employment militate against training and skills development. Cost pressures on employers impact upon their propensity to invest in training for non 'core' workers. A final driver of polarisation relates to labour market policies and institutions. National education and training policy has largely been designed to focus on those with low skills, while employment protection via legislation and regulation has receded as new forms of work have emerged. Given evidence on an association between union presence and access to training and development, union decline removes a support for skills formation, particularly at the bottom of the occupational hierarchy.

Research on polarisation is contested. Research from the European jobs monitor (Fernández-Macías \& Hurley, 2014) presents a contrary picture to previous research, finding no clear association between the routine content of jobs and the polarisation of job structures. This research acknowledges that 
routine jobs are growing more slowly than other jobs, but notes that this drives upgrading, not polarisation, and argues that polarisation is not explained either by technological change or globalisation but more likely by the weaknesses of labour market institutions.

Part of the challenge in understanding changes in skill trajectories is that skill is a multi-dimensional construct and uneven variation across dimensions creates complex patterns of skills change. So, it is possible, for example, that tasks become more complex while autonomy or control over those tasks is reduced - this position has been argued by Spenner (1983) and by Felstead et al. (2002). Polarisation risks significant human capital depletion over time, and while considerable policy concern exists over this, as yet policy responses continue to focus primarily on bolstering skill supply. The changing nature of work will require considerable policy creativity in supporting skills supply over the life course of in the context of new forms of employment. This means that 'new arrangements will have to be crafted to effectively share the burden of (regular) training between individual workers, employers, and the state' (EPSC, 2016, p. 9).

\section{Skills utilisation}

Having skills is one thing; having a job whose demands are commensurate with one's skills, and provides the opportunity to use one's skills, is another. There are significant negative returns to education and skills where individuals find themselves in a job requiring lower entry qualifications than they have, compared to individuals whose education, skills and occupation are better aligned (Hanushek, et al., 2013). This points to the importance not just of skills attainment but of opportunities for effective skills utilisation.

Public investment in education and skills programmes, particularly in LMEs, is aimed at increasing the supply of skills and enhancing human capital in order to boost the demand for skills, and assumes, as Keep (2016) noted, a Say's Law effect where the supply of skills boosts the demand for skills. The discussion will return later to the effectiveness - or otherwise - of skills as a silver bullet to solve the problems facing individuals and national economies. In this section, the alignment between skill levels and skill deployment, commonly discussed with reference to the concept of skills utilisation or, more prominently in debates in Australia, Britain and in Europe, skills under-utilisation (Findlay \& Warhurst, 2012; Skills Australia, 2012) is considered.

Skills under-utilisation occurs when acquired work-related skills are not used in the workplace. For the OECD (2011), skills formation and skills utilisation are two sides of the same coin, with the ways in which skills are used equally important as how they are obtained and developed in the first instance'. Skills under-utilisation imposes costs on organisations and individuals - 'failure to make active use of skills may lead to depreciation of existing skills; it might even lead to a loss of the skills already acquired' (OECD, 2011, p. 19). Under-utilisation of skills also fails to capitalise fully on public (and individual) investment in skills formation at primary, secondary, tertiary and workplace levels.

Skills under-utilisation is related to, but distinct from, the concept of over-qualification, where an individual has a higher educational level than that required to access their current job. Skills underutilisation can be measured either by comparing the qualifications profile of job holders to the qualifications requirements of their job, or by surveys that ask individuals whether their work-related skills are fully utilised at work, though Keep (2016) argued that most of the extant British-based research relies on the former rather than the latter.

Keep provided an extensive review of research on skills under-utilisation, primarily but not exclusively for Britain. Drawing upon the OECD 2013 Adult Skills Survey which asked workers across 22 countries 
about the skill requirements of their jobs and their perceptions of how extensively their skills were used, described the results for England and Northern Ireland as 'bleak' (Keep, 2016, p. 12). He cited a number of research studies that estimate skills under-utilisation as a feature of upwards of one third of jobs (Brinkley, et al., 2009; Felstead, et al., 2013), and identified it as more problematic in some sectors and occupations, particularly for those in low paid work (Wright \& Sissons, 2012; Sissons \& Jones, 2014). Skills under-utilisation also has an important geographical dimension, with $39 \%$ of employees in Rochdale, for example, respectively considered to be overqualified for their current role compared with around 5\% in Hull, with negative implications for workers' pay and progression as well as for firm productivity (Clayton, et al., 2014).

While skills under-utilisation appears on the face of it to be a problem for human capital theory, Autor and Handel noted that the human capital model is 'not directly informative about the demand side of the human capital market' (2013, p. 560), saying little about employers' demands for skills. Understanding why employers may fail to deploy skills available in their workforces might be enhanced by consideration of both employers' hiring approaches and of business models that emphasise low-cost, low value added products and services. Both considerations are reflected in Findlay and Warhurst's (Findlay \& Warhurst, 2012) distinction between employers' demands for skills and qualifications to get a job (Type 1 demand) and employers' demands for skills to actually do a job (Type 2 demand). The availability of labour with high levels of acquired qualifications as a consequence of expansion in further and higher education may have driven employers to increase credentialism, that is, increase their Type 1 demand. This does not, however, impact the skills needed to do a job so relative Type 2 demand lags. Type 2 demand is also affected by forms of work design that limit the opportunities to use workers' skills. Credentialism increases over-qualification, while certain forms of job design and management control systems can contribute to skills under-utilisation. Where workers skills are under-utilised, Findlay and Warhurst advocated better use of skills in order to harness the untapped potential of workers and lever existing sunk costs in skills acquisition. Better use of skills, however, requires corresponding changes in job design and organisational and management practice, and in the absence of employer concern over skills under-utilisation, this may be unlikely. As Findlay and Warhurst noted: 'If more effective skills utilisation is now the policy priority, its firm-level practice is weak. The reason, we argue, is that many employers perceive it as a policy solution to a problem that does not exist' (Findlay \& Warhurst, 2012, p. 5). In this regard, there is a significant tension between policy interventions that support (and invest in) skills expansion and low cost, low value but still profitable business models.

Findlay and colleagues (Findlay, et al., 2015; Findlay, et al., 2016a; Findlay, et al., 2016b) have argued that workplace innovation practices can create the conditions for better skills usage at work, with the potential to benefit workers and organisations. Their analysis builds on the EU definition of workplace innovation as referring - notably but not only to - innovations in the ways enterprises are structured; the way they manage their human resources; internal decision-making and innovation processes are devised; relationships with clients or suppliers are organised; and work environment and internal support systems are designed. Their work engages critically with this concept of workplace innovation, arguing that while innovation in workplace practice can deliver better opportunities for acquired skills to be deployed, this is a necessary but insufficient condition for more effective skills utilisation and greater discretionary employee effort. Some share in the benefits of better skills utilisation and more innovative practice is required to cement skills formation, deployment and effectiveness. This takes then returns to the role of skills valuation and the returns to skill, and to the role of policy levers in encouraging and supporting both skills acquisition and the demand for skills.

\section{Skills policy and institutional context}


Skills policy and practice exists within specific institutional contexts. As Hall and Soskice's (2001) work on varieties of capitalism suggested, historical trajectories across countries create 'institutional complementarities' formed by legal, economic and social norms that shape distinctive national skills systems. Toner's (2011) review for the OECD clearly outlined the way in which the nature, quantity and quality of skills reflect national institutional configurations. Focussing on intermediate or vocational skills, Toner, following Clark and Winch (2006), highlights the characteristics of simplified ideal type occupational, internal and flexible skills formation systems. Toner's framework is adapted in Table 1 below. 
Table 1: National differences in skills formation regimes

\begin{tabular}{|c|c|c|c|}
\hline & Flexible & Occupational & Internal \\
\hline Country example & UK VET & $\begin{array}{l}\text { German apprenticeship } \\
\text { system }\end{array}$ & $\begin{array}{l}\text { Large Japanese firms } \\
\text { (especially in } \\
\text { manufacturing) }\end{array}$ \\
\hline $\begin{array}{l}\text { Key characteristic } \\
\text { of skills system }\end{array}$ & Skills polarisation & $\begin{array}{l}\text { Broad based } \\
\text { apprenticeship training } \\
\text { for many }\end{array}$ & $\begin{array}{l}\text { Core and peripheral } \\
\text { workers }\end{array}$ \\
\hline Conception of skill & $\begin{array}{l}\text { Attribute or property of } \\
\text { an individual }\end{array}$ & $\begin{array}{l}\text { Skill/production as a } \\
\text { social activity }\end{array}$ & $\begin{array}{l}\text { Skill/production as a } \\
\text { collective company- } \\
\text { focussed activity }\end{array}$ \\
\hline $\begin{array}{l}\text { VET knowledge } \\
\text { and practice }\end{array}$ & $\begin{array}{l}\text { Practice focussed - } \\
\text { physical and manual } \\
\text { dexterity to perform } \\
\text { discrete tasks; lower } \\
\text { knowledge emphasis }\end{array}$ & $\begin{array}{l}\text { High educational } \\
\text { attainment within } \\
\text { apprenticeships }\end{array}$ & $\begin{array}{l}\text { High average } \\
\text { educational level } \\
\text { underpins higher } \\
\text { level vocational } \\
\text { training, }\end{array}$ \\
\hline $\begin{array}{l}\text { Level of certified } \\
\text { skills }\end{array}$ & $\begin{array}{l}\text { Low poorly performing } \\
\text { VET sector; low level of } \\
\text { certified skills in } \\
\text { apprenticeships; }\end{array}$ & High & $\begin{array}{l}\text { Core workforce } \\
\text { receives mostly on } \\
\text { the job training } \\
\text { designed for firm- } \\
\text { specific needs }\end{array}$ \\
\hline $\begin{array}{l}\text { Worker incentives } \\
\text { to train }\end{array}$ & $\begin{array}{l}\text { Low - low employer } \\
\text { demand for higher } \\
\text { intermediate skills }\end{array}$ & $\begin{array}{l}\text { High - welfare provision } \\
\text { and employment } \\
\text { protection incentivise } \\
\text { occupational skills } \\
\text { acquisition }\end{array}$ & $\begin{array}{l}\text { High - workers invest } \\
\text { in firm-specific } \\
\text { training in return for } \\
\text { employment security } \\
\text { and a career path }\end{array}$ \\
\hline $\begin{array}{l}\text { Employer incentive } \\
\text { to train }\end{array}$ & $\begin{array}{l}\text { focus on cost-minimising } \\
\text { and firm-specific training }\end{array}$ & $\begin{array}{l}\text { Focus on higher value } \\
\text { skills and broad } \\
\text { occupational training }\end{array}$ & $\begin{array}{l}\text { Focus on firm specific } \\
\text { job training, } \\
\text { multiskilling and } \\
\text { functional flexibility }\end{array}$ \\
\hline $\begin{array}{l}\text { Macro skills } \\
\text { context }\end{array}$ & $\begin{array}{l}\text { Employers' interests } \\
\text { dominate }\end{array}$ & $\begin{array}{l}\text { Tripartite co-ordination } \\
\text { between State, } \\
\text { employer associations } \\
\text { and TUs }\end{array}$ & $\begin{array}{l}\text { Institutionally stable } \\
\text { industrial relations }\end{array}$ \\
\hline $\begin{array}{l}\text { Wages and } \\
\text { industrial relations }\end{array}$ & $\begin{array}{l}\text { Low wages; low levels of } \\
\text { unionisation; mainly } \\
\text { enterprise based } \\
\text { bargaining }\end{array}$ & $\begin{array}{l}\text { High wages; industry } \\
\text { level bargaining creates } \\
\text { uniform wages for } \\
\text { occupations across } \\
\text { firms and deters price } \\
\text { competition via low pay }\end{array}$ & $\begin{array}{l}\text { High wages for core } \\
\text { linked to experience } \\
\text { and tenure; } \\
\text { decentralised and } \\
\text { non-confrontational } \\
\text { industrial relations. }\end{array}$ \\
\hline Role of regulation & $\begin{array}{l}\text { Limited labour market } \\
\text { regulation }\end{array}$ & $\begin{array}{l}\text { Extensive labour market } \\
\text { regulation }\end{array}$ & $\begin{array}{l}\text { Company regulation } \\
\text { predominates within } \\
\text { key sectors, but more } \\
\text { limited regulation for } \\
\text { peripheral workers }\end{array}$ \\
\hline $\begin{array}{l}\text { Employment } \\
\text { security }\end{array}$ & $\begin{array}{l}\text { Numerical flexibility is a } \\
\text { priority; relative ease of } \\
\text { hiring and firing; high }\end{array}$ & $\begin{array}{l}\text { High employment } \\
\text { security increases } \\
\text { worker acceptance of } \\
\text { new technologies, }\end{array}$ & $\begin{array}{l}\text { For core, high job } \\
\text { security; peripheral } \\
\text { employment is } \\
\text { adjusted to }\end{array}$ \\
\hline
\end{tabular}




\begin{tabular}{|l|l|l|l|}
\hline & $\begin{array}{l}\text { labour turnover in non- } \\
\text { union sector }\end{array}$ & $\begin{array}{l}\text { knowledge sharing and } \\
\text { willingness to acquire } \\
\text { skills }\end{array}$ & fluctuations in output \\
\hline $\begin{array}{l}\text { Role of } \\
\text { government }\end{array}$ & $\begin{array}{l}\text { Few activist state } \\
\text { industry policies }\end{array}$ & $\begin{array}{l}\text { Active industry policy - } \\
\text { virtuous circle of supply } \\
\text { and demand for skills }\end{array}$ & $\begin{array}{l}\text { Active industry policy } \\
\text { based on close co- } \\
\text { operation between } \\
\text { government and } \\
\text { private firms }\end{array}$ \\
\hline $\begin{array}{l}\text { Role of } \\
\text { occupational } \\
\text { licencing }\end{array}$ & $\begin{array}{l}\text { Limited - reduces } \\
\text { incentives for employers } \\
\text { and employees to invest } \\
\text { in training }\end{array}$ & Extensive & $\begin{array}{l}\text { Limited - reliance on } \\
\text { company-specific } \\
\text { training and } \\
\text { identification }\end{array}$ \\
\hline $\begin{array}{l}\text { Relationship to } \\
\text { productivity }\end{array}$ & $\begin{array}{l}\text { low-skill equilibrium' - } \\
\text { low skill, low } \\
\text { productivity workers } \\
\text { producing standardised, } \\
\text { low quality goods and } \\
\text { services }\end{array}$ & $\begin{array}{l}\text { High wages incentivise } \\
\text { employers to maximise } \\
\text { productivity returns on } \\
\text { skills investments }\end{array}$ & $\begin{array}{l}\text { High levels of } \\
\text { training, multiskilling, } \\
\text { job rotation and } \\
\text { group problem } \\
\text { solving support } \\
\text { productivity }\end{array}$ \\
\hline $\begin{array}{l}\text { Relationship to } \\
\text { innovation }\end{array}$ & $\begin{array}{l}\text { Focus on narrow firm } \\
\text { specific skill sets - less } \\
\text { likely to support } \\
\text { innovation }\end{array}$ & $\begin{array}{l}\text { breadth and depth of } \\
\text { practical and theoretical } \\
\text { skills encourages multi- } \\
\text { skilling and adaptability }\end{array}$ & $\begin{array}{l}\text { higher level } \\
\text { vocational training } \\
\text { and active } \\
\text { participation in } \\
\text { production process } \\
\text { supports flexibility to } \\
\text { introduce new } \\
\text { technologies }\end{array}$ \\
\hline
\end{tabular}

Source: Adapted from research review presented in Toner (2008).

While these ideal types disguise significant variation, a key defining feature of more co-ordinated market economies (CMEs) is the collective responsibility for skills across relevant stakeholders and the stability of institutional structures that support collective or tripartite approaches to skills, while in LMEs greater reliance on individual responsibility for skills development rest with the individual and employers have a more prominent role in shaping skills demand and usage. Considering skills in the context of broader workplace, organisational and industry practices highlights the complexity of incentives and disincentives, costs and barriers to attaining, deploying and benefitting from vocational skills in LMEs like that of Britain. The reluctance of the state to intervene more directly in workplaces leaves only limited policy levers available - hence, the focus on skills supply and on education, training and skills as a 'panacea' (Keep \& Mayhew, 2010). The case for making this investment has largely been that it will lead to significant gains in national economic performance

More recently, however, the limitations of skills as a panacea has been increasingly recognised in a number of different ways, most notable that skills supply does not create its own demand. As the OECD have noted: 'more skills are not necessarily better skills, and the mere existence of skills does not automatically lead to improved economic performance' (OECD, 2011, p. 19).

Despite these challenges, skills and their value remains a core concern of workers, unions, employers, policy makers and citizens. Even in LMEs, unions have an interest in skills debates - longstanding in terms of, for example, joint responsibility for apprenticeships, and of more recent origin in policies 
and practice around union-based learning. In Britain, unions, through union-led learning, have delivered skills and learning support to workers who are least likely to receive it (Findlay, et al., 2011). In Scotland, unions and the Scottish Trades Union Congress (STUC) have developed an increasingly influential voice on skills formation through their involvement in union-led learning and through union engagement in skills utilisation debates and projects.

Moving beyond the parameters of acquiring skills takes us to a different and more contested terrain in two key respects. First, improving the use of and demand for skills requires employers to engage in, and other workplace stakeholders to engage with employers on, broader organisational and business development (Findlay \& Warhurst, 2012; Keep, 2016). Second, it requires not just supportive skills policies but more state intervention in industrial policies that help influence employers to make better use of skills and to use better skills to support higher value business activities. Yet addressing this intersection of national economic policies and industrial agendas with employers' business and workforce development approaches is complex and challenging and has not been a high priority for government at a UK level.

While there is increasing recognition in policy circles of skills formation and development throughout the life course (EPSC, 2016), the predominant debate on skills policy in Britain consistently gives primacy to employer leadership and there are fewer opportunities for alternative stakeholder voices. Individuals can, of course, invest in their own skills but within heavily constrained parameters given that they cannot shape the nature of occupations and organisations. Moreover, continuing pressures on public budgets limit the leverage of public intervention in the skills system, even though this may prove short sighted in constraining longer term economic growth and living standards (Handel, 2016).

There are, however, more promising developments in Scotland, where the Scottish Government has engaged in a broader and more inclusive debate on skills and skills policy. Scotland has been at the forefront of debates on improving skills utilisation and in recent years researchers, policy makers and some practitioners have engaged in a more developed debate around the need to redesign work and workplaces to make better use of skills (Findlay, et al., 2016b), captured in initiatives to support greater workplace innovation (Findlay, et al., 2016a). Crucially, these initiatives have been underpinned by a mutual gains approach to skills and organisational innovation in which improving skills and job quality are seen as the drivers of improved business and economic performance and by engagement and dialogue with unions and other workplace stakeholders. More recently, these debates have begun to impact upon the strategy and operations of public skills and economic development agencies in Scotland in their supports to businesses. While it is early days for these approaches, and while the constraints of the wider macro-economic framework and British regulatory framework remain considerable, a constructive and inclusive debate about the link between skills, job quality, workforce and workplace development and national economic performance has much to commend it. More recently, UK level debates on productivity and decent work have begun to open up a broader appreciation of importance of doing more than supplying skills to the market, though without stronger institutional supports, significant developments in these areas seem unlikely. That greater skills policy divergence is emerging between the UK and its devolved nations, however, serves to highlight that there are real choices to be made in skills policy, choices that are shaped by competitive and institutional factors but are, crucially, the subject of political choice. Political choices that recognise the opening point of this chapter - that skills matter to and beyond economic impact are more likely to frame expansive and innovative debates about skill. For the UK, the decision to leave the EU will raise many pressing issues not just about access to skilled workers but also about the implications for business models and competitive strategies. Political decisions will shape the choice between low cost competitive strategies on the one hand, and economic models that can most effectively amortise public and individual investment in skills formation on the other. 


\section{Conclusion}

Skills lie at the heart of work and of individual and social life. The opportunity to acquire, deploy, develop and to be rewarded for skill is crucial to economic prosperity and to the quality of working life, as well as to life beyond work. Yet there are marked variations in how these opportunities are available to particular groups of workers which impacts not only on individuals but on the social return to skills. Addressing this is challenging: skill formation is complex and contested, shaped by global and national economic and political forces but also by how employers choose to use and generate skills, and the opportunities for other stakeholders, such as unions, to have an informed and influential voice in skills policy debates. However, notwithstanding broader market and structural constraints, mutual gains approaches to skills formation and development offer perhaps the best opportunity for improving the economic, social and individual value of skills. 


\section{Bibliography}

Acemoglu, D. \& Autor, D. (2011), 'Skills, tasks and technologies: Implications for employment and earnings'. In: O. Ashenfelter \& D. Card, eds. Handbook of labor economics, Volume 4. Amsterdam: Elsevier, pp. 1043-1171.

Arulampalam, W. \& Booth, A. (1998), 'Training and Labour Market Flexibility: Is There a Trade-off?', British Journal of Industrial Relations, 36(4), 521-536.

Attewell, P. (1987), 'The Deskilling Controversy', Work and Occupations, 14(3), 323-346.

Autor, D. (2010), The Polarization of Job Opportunities in the U.S. Labour Market: Implications for Employment and Earnings, Washington DC: Centre for American Progress and the Hamilton Project. Autor, D. \& Handel, D. H. (2013), 'Putting Tasks to the Test: Human Capital, Job Tasks, and Wages', Journal of Labour Economics, 31(2), s59-s96.

Barley, S. R. (1996), 'Technicians in the Workplace: Ethnographic Evidence for Bringing Work into Organizational Studies', Administrative Science Quarterly, 41(3), 404-441.

Beaudry, P., Green, D. A. \& Sand, B. M. (2013), 'The Great Reversal in the Demand for Skill and Cognitive Tasks', Journal of Labor Economics, 34(s1), s199-s247.

BIS, (2011), The Returns to Higher Education Qualifications, London: Department for Business, Innovation and Skills.

Blauner, R. (1964), Alienation and freedom: the factory worker and his job. 1 ed. Chicago: University of Chicago Press.

Braverman, H. (1974), Labor and monopoly capital: The degradation of work in the twentieeth century. 1 ed. New York: Monthly Review Press.

Brinkley, I., Fauth, R, Mahdon, M. \& Theodoropoulou, S. (2009), Knowledge Workers and Knowledge Work, London: Work Foundation.

Brynjolfsson, E. \& McAfee, A. (2014), The Second Machine Age: Work, Progress, and Prosperity in a Time of Brilliant Technologies. 1 ed. New York: W. W. Norton \& Company Ltd.

Cain, P. S. \& Treiman, D. J. (1981), 'The Dictionary of Occupational Titles as a Source of Occupational Data', American Sociological Review, 45(3), 253-278.

Cedefop (2012), Building on skills forecasts - Comparing methods and applications. Research Paper No. 18. Luxembourg, Publiciations Office of the European Union.

Clarke, L. \& Winch, C. (2006), 'A European skills framework? - but what are skills? Anglo-Saxon versus German concepts', Journal of Education and Work, 19(3), 255-269.

Clayton, N., Williams, M. \& Howell, A. (2014), Unequal opportunities, how jobs are changing cities, London: Centre for Cities.

Cockburn, C. (1983), Brothers: Male Dominance and Technological Change. 1 ed. London: Pluto.

Draca, M. \& Green, C. (2004), 'The Incidence and Intensity of Employer Funded Training: Australian Evidence on the Impact of Flexible Work' Scottish Journal of Political Economy, 51(5), 609-625.

Edwards, P. (2010), Skills and the Small Firm: A Research and Policy Briefing, Wath-upon-Dearn: UKCES.

EPSC (2016), The Future of Work: skills and resilience for a world of change. EPSC strategic notes, Issue 1310 June, 1-12.

Esposto, A. (2008) 'Skill: An Elusive and Ambiguous Concept in Labour Market Studies', Australian Bulletin of Labour, 34(1), 100-124.

Felstead, A., Gallie, D. \& Green, F. (2002) Work Skills in Britain 1986-2001, Nottingham: DfES

Publications.

Felstead, A., Gallie, D., Green, F. \& Inanc, H. (2013), Felstead, A., Gallie, D., Green, F., and Inanc, H Skills at Work in Britain, First Findings from the Skills and Employment Survey, 2012, London: Institute of Education, LLAKES.

Felstead, A., Gallie, D., Green, F. \& Zhou, Y. (2007), Skills at Work, 1986 to 2006, Universities of Oxford and Cardiff: ESRC Centre on Skills, Knowledge and Organisational Performance. 
Fernández-Macías, E. \& Hurley, J. (2014), European Jobs Monitor 2014: Drivers of Recent Job Polarisation and Upgrading in Europe, Dublin: European Foundation for the Improvement of Living and Working Conditions.

Fernandez, R. M. \& Hayward, G. (2004), 'Qualifying for a job: an educational and economic audit of the English 14-19 education and training system', In: G. Hayward \& S. James, eds. Balancing the Skills Equation. Key Issues for Policy and Practice. Bristol: Policy Press, 77-100.

Findlay, J., Findlay, J. \& Stewart, R. (2009), The consequences of caring: skills, regulation and reward among early years workers, Work, Employment and Society, 23(3), 422-441.

Findlay, P. et al. (2015), Innovating Works ... improving work and workplaces: Workplace Innovation in small to medium sized enterprises in Scotland, Glasgow: University of Strathclyde.

Findlay, P. et al. (2017b) 'Employer Choice and Job Quality: Workplace Innovation, Work Redesign, and Employee Perceptions of Job Quality in a Complex Health-Care Setting', Work and Occupations, 44(1), 113-136.

Findlay, P. et al. (2016a), Exploring the evidence: opportunities for fair, innovative and transformative work in Scotland, Glasgow: University of Strathclyde.

Findlay, P. et al. (2016b) Networks and collaboration: Driving fair, innovative and transformative work in Scotland, Glasgow: University of Strathclyde.

Findlay, P. \& Warhurst, C. (2012), 'More Effective Skills Utilisation: Shifting the Terrain of Skills Policy in Scotland', Cardiff: SKOPE, University of Cardiff.

Findlay, P. \& Warhurst, C. (2012) More Effective Skills Utilisation: Shifting the Terrain of Skills Policy in Scotland, Cardiff: SKOPE, Cardiff University.

Findlay, P., Warhurst, C. \& Commander, J. (2011) The Role of Trade Unions in Effective Skills

Utilisation: three Scottish case studies, Glasgow: Scottish Trades Union Congress.

Findlay, P., Warhurst, C., Keep \& Lloyd, C. (2017a) 'Opportunity Knocks? The Possibilities and Levers for Improving Job Quality', Work and Occupations, 44(1), 3-22.

Gallie, D. (1999), 'The polarisation of the labour market and exclusion of vulnerable groups', In: K. Isaksson, C. Hogstedt, C. Eriksson \& T. Theorell, eds. Health Effects of the New Labour Market. New York: Kluwer, 245-266.

Gottfried, H. (2006) 'Feminist Theories of Work', In: M. Korczynski, R. Hodson \& P. K. Edwards, eds. Social Theory at Work. Oxford: Oxford University Press, 121-54.

Green, F. (2011) What is Skill? An Inter-Disciplinary Synthesis published by the Centre for Learning and Life Chances in Knowledge Economies and Societies, available at: http://www.llakes.org., London: Centre for Learning and Life Chances in Knowledge Economies and Societies.

Green, F. (2012), 'Employee Involvement, Technology and Evolution in Job Skills: A Task-Based Analysis', Industrial and Labour Relations Review, 65(1), 35-66.

Green, F., Felstead, A., Gallie, D. \& Henseke, G. (2016), 'Skills and work organisation in Britain: a quarter century of change', Journal of Labour Market Research, 49, 121-132.

Green, F., Felstead, A., Gallie, D. \& Henseke, G. (2016) 'Skills and work organisation in Britain: a quarter century of change', Journal of Labour Market Research, 49, 121-132.

Grimshaw, D. \& Rubery, J. (2007) Undervaluing Women's Work, London: EOC.

Grugulis, I. (2004), Skills, Training and Human Resource Development: A Critical Text. 1 ed. London:

Palgrave Macmillan.

Grugulis, I., Keep, E. \& Warhurst, C. (2004) 'Whatever happened to skill?;, In: C. Warhurst, E. Keep \& I. Grugulis, eds. The Skills That Matter. New York: Palgrave Macmillan, 1-18.

Hall, P. A. \& Soskice, D. (2001) Varieties of Capitalism: The Institutional Foundations of Comparative Advantage. 1 ed. Oxford: Oxford University Press.

Hampson, I. \& Junor, A. (2005), 'Articulation Work Skills and the Recognition of Call Centre Competence in Australia', Journal of Industrial Relations, 51(1), 45-58.

Handel, M. J. (2016), 'What do people do at work? A profile of U.S. jobs from the survey of workplace Skills, Technology, and Management Practices (STAMP)', Journal of Labour Market Reearch, 49, 177-197. 
Hanushek, E. A., Schwerdt, G., Wiederhold, S. \& Woessmann, L. (2013), Returns to skill around the world: Evidence from PIAAC, Cambridge, MA: NBER.

Heckman, J. J. \& Kautz, T. D. (2012) Hard Evidence on Soft Skills, Cambridge, MA: NBER.

Hochschild, A. R. (1983), The Managed Heart. 1 ed. Berkeley, CA: University of California Press. Howell, D. R. \& Wolff, E. N. (1991), 'Trends in the Growth and Distribution of Skills in the U.S. Workplace, 1960-85', Industrial and Labour Relations Review, 44(3), 486-502.

ILO (2014), Skills mismatch in Europe, Geneva: International Labour Office.

Keep, E. (2016), Improving Skills Utilisation in the UK - Some Reflections on What, Who and How?, Oxford: Centre on Skills, Knowledge and Organisational Performance.

Keep, E. J. \& Payne, J. (2004), ' 'I can't believe it's not skill': the changing meaning of skill in the UK context and some implications', In: G. Hayward \& S. James, eds. Balancing the Skills Equation Key Issues and Challenges for Policy and Practice. Bristol: Policy Press, 53-76.

Keep, E. \& Mayhew, K. (1999), 'The Assessment: Knowledge, Skills and Competitiveness', Oxford Review of Economic Policy, 15(1), 1-15.

Keep, E. \& Mayhew, K. (2010), 'Moving beyond skills as a social and economic panacea', Work, Employment and Society, 24, 565-577.

Keep, E. \& Mayhew, K. (2014), Industrial strategy and the future of skills policy - the high road to sustainable growth, London: Chartered Institute for Personnel and Development.

Kim, Y.-H. (2002), 'A State of Art Review on the Impact of Technology on Skill Demand in OECD Countries', Journal of Education and Work, 15(1), 89-109.

Lafer, G. (2002) The Jobs Training Charade. 1 ed. Ithaca and London: Cornell University Press. Laurison, D. \& Friedman, S. (2016), 'The Class Pay Gap in Higher Professional and Managerial Occupations', American Sociological Review, 81(4), 668-695.

Leitch Review of Skills (2006) Prosperity for All in the Global Economy - World Class Skills, London: HM Treasury.

Lindsay, C., Canduela, J. \& Raeside, R. (2012) 'Polarization in access to work related training in Britain', Economic and Industrial Democracy, 34(2), 205-225.

Littler, C. R. (1982), The Development of the Labour Process in Britain, Japan and USA. 1 ed. London: Hei1mann.

Lloyd, C. \& Payne, J. (2009), 'Full of sound and fury, signifying nothing': interrogating new skill concepts in service work - the view from two UK call centres', Work, Employment and Society, 23(4), 617-634.

Lloyd-Ellis, H. \& Roberts, J. (2002), 'Twin Engines of Growth: Skills and Technology as Equal Partners in Balanced Growth', Journal of Economic Growth, 7(2), 87-115.

Machin, S. \& Van Reenan, J. (1998), 'Technology and Changes in Skill Structure: Evidence from Seven OECD Countries', The Quarterly Journal of Economics, 113(4), 1215-1244.

Marr, B. (2016), 'Surprisingly, These 10 Professional Jobs Are Under Threat From Big Data', Forbes Magazine, 25 April.

McIntosh, S. \& Morris, D. (2016), Labour Market Returns to Vocational Qualifications in the Labour Force Survey, London: Centre for Vocational Education Research.

Moss, P., Boddy, J. \& Cameron, C. (2006), 'Care Work, Present and Future: Introduction', In: J. Boddy, C. Cameron \& P. Moss, eds. Care Work. Oxford: Routledge, 3-17.

Moss, P. \& Tilly, C. (1996), "Soft" Skills and Race: An Investigation of Black Men's Employment Problems, Work and Occupations, 23(3), 252-276.

OECD (1998), The Future of Female-Dominated Occupations, Paris: OECD.

OECD (2011), Towards an OECD Skills Strategy, Paris: OECD.

ONS (2015), Analysis of the UK labour market - estimates of skills mismatch using measures of over and under education, London: Office for National Statistics.

ONS (2016), Analysis of the UK labour market - estimates of skills mismatch using measures of over and under education: 2015, London: ONS. 
Payne, J. (2010) Skills Utilisation: Towards a Measurement and Evaluation Framework, Universities of Cardiff and Oxford: SKOPE.

Phillips, A. \& Taylor, B. (1980), 'Sex and Skill: Notes towards a Feminist Economics', Feminist Review, 6, 79-88.

Sissons, P. \& Jones, K. (2014), How can local skills strategies help low earners? York: Joseph Rowntree Foundation.

Skills Australia (2012), Better use of skills, better outcomes: a research report on skill utilisation in Australia, Canberra: Skills Australia.

Sousounis, P. \& Bladen-Hovell, R. (2010) 'Persistence in the determination of work-related training participation: Evidence from the BHPS, 1991-1997', Economics of Education Review, 29(6), 10051015.

Spenner, K. I. (1983), 'Deciphering Prometheus: Temporal change in the skill level of work, American Sociological Review, 48, 824-837.

Steinberg, R. J. (1990), 'Social Construction of Skill: Gender, Power, and Comparable Worth', Work and Occupations, 17(4), 449-82.

Steinberg, R. J. (1999), 'Emotional Labor in Job Evaluation: Redesigning Compensation Practices', Annals of the American Academy of Political and Social Science, 561(1), 143-57.

Steinberg, R. J. \& Figart, D. M. (1999), 'Emotional Labor since the Managed Heart', Annals of the American Academy of Political and Social Science, 561(1), 8-26.

Storey, J. \& Salaman, G. (2008), Business Models and their Implications for Skills, Universities of Cardiff and Oxford: ESRC SKOPE.

Tholen, G., James Relly, S., Warhurst, C. \& McQuarrie, J. (2016), 'Higher education, graduate skills and the skills of graduates: the case of graduates as residential sales estate agents', British Educational Research Journal, 42(3), 408-523.

Tomlinson, M. (2008) 'The degree is not enough': Students' perceptions of the role of higher education credentials for graduate work and employability', British Journal of Sociology of Education, 29(1), 49-61.

Toner, P. (2011) Workforce Skills and Innovation: An Overview of Major Themes in the Literature, Paris: OECD Publishing.

Vallas, S. P. (1990) 'The Concept of Skill: A Critical Review', Work and Occupations, 17(4), 379-398. Warhurst, C., Tilly, C. \& Gatta, M. (2017), 'A New Social Construction of Skill'. In: C. Warhurst, K. Mayhew, D. Finegold \& J. Buchanan, eds. The Oxford Handbook of Skills and Training. Oxford: Oxford University Press, 72-91.

Wolf, A. (2004), 'Education and Economic Performance: Simplistic theories and their Policy Consequences', Oxford Review of Economic Policy, 20(2), 315-333.

Wright, J. \& Sissons, P. (2012), 'The Skills Dilemma, Skills Under-Utilisation and Low-Wage Work', London: Work Foundation.

Wright, J. \& Sissons, P. (2012), The Skills Dilemma, Skills Under-Utilisation and Low-Wage Work, London: Work Foundation. 